\title{
"We raise up the voice of the voiceless": Voice, Rights, and Resistance amongst Congolese Human Rights Defenders in Uganda ${ }^{\mathbf{1}}$
}

\author{
KATIE R.V. MCQUAID
}

\begin{abstract}
Amongst Uganda's Congolese refugee population are a number of human rights defenders who actively resist the construction of refugees as dispossessed and displaced humanitarian aid recipients. Upon fleeing the complex and violent conflicts of the Democratic Republic of Congo, rather than supplicate to a humanitarian regime saturated with the language of human rights, these young men draw on human rights to "raise up the voice of the voiceless." This article explores how defenders draw on human rights to understand, articulate, and resist the constraints of forced displacement into a humanitarian regime.
\end{abstract}

\section{Résumé}

Parmi les réfugiés d'origine congolaise en Ouganda se trouvent un certain nombre de défenseurs des droits de la personne qui résistent activement à la construction conceptuelle des réfugiés selon laquelle ils seraient tout simplement des bénéficiaires d'aide humanitaire démunis et déplacés. Après avoir fui les conflits complexes et violents qui ont ravagé la République démocratique $d u$ Congo, plutôt que d'être réduits à un statut de suppliants envers un régime humanitaire saturé par le discours des droits de la personne, ces jeunes hommes préfèrent puiser dans ces mêmes droits pour "donner voix à ceux qui n'ont pas de voix ». Cet article s'engage dans une exploration $d u$ processus selon lequel les droits de la personne peuvent se transformer en terrain fertile qui permet à ces défenseurs des droits de comprendre, d'articuler et de résister aux contraintes du déplacement forcé au sein d'un régime humanitaire.

$\mathrm{D}$ rawing on a long-term ethnographic study of Congolese human rights defenders (HRD) who have fled into Uganda, this article offers insight into the practices and experiences of those who call themselves the "voice of the voiceless," and who are known as "human rights" by the communities they strive to defend. Forced to flee violent persecution for their work as HRD in the Democratic Republic of Congo (DRC), these young Congolese men represent a crucial and under-researched, under-supported, and under-reported part of contemporary Congolese struggles at home and in displacement. This article focuses on the work of these HRD in Uganda, exploring how they draw on human rights to understand, articulate, and resist the constraints of forced displacement into a humanitarian regime.

After setting out the scope of my research and the data upon which this article is based, the first section briefly elucidates the conditions leading to the forced displacement of refugees into Uganda and examines the ways in which defenders themselves come to embody "human rights" for the wider population. The second and third sections focus on refugee life in Uganda, and more specifically the actions of HRD amidst the urban refugee population in Kampala. It draws upon the reflections of several HRD to demonstrate how exercising voice in the pursuit of human rights is about 
more than deploying rights discourses in the construction of political claims and documents. It is about embodied knowledge, using human rights as a critical vehicle for subjectivity, solidarity, and action. It is in engaging with the perspectives of those in the refugee population who regularly draw on human rights language, and who are often the only ones to whom the wider refugee community can turn for information and guidance, that we are compelled, I argue, to confront the contradictions of human rights practice, both in humanitarian work and in defenders' actions. In the final section, this article highlights some of these contradictions through engaging a political understanding of human rights.

This article draws together literatures on both humanitarianism and human rights to consider the multiple ways in which humanitarianism is navigated and contested by HRD using the language of human rights. In particular, it engages with a humanitarian politics centring on notions of victimhood. ${ }^{2}$ Malkki, amongst others, argues how a de-historicizing universalism of humanitarianism creates a context in which it is difficult for people in the refugee category to be approached as historical actors rather than simply as mute victims. ${ }^{3}$ This in turn highlights a general trend in international humanitarianism whereby universalized and standardized identities of suffering are established through personal testimony about international human rights violations. ${ }^{4}$ Many refugees in such contexts end up limited to exercising what Utas terms "victimcy," the agency of hiding one's actions in passive victimhood. 5

It is argued that once one is constructed as a humanitarian victim, this subjugated subjectivity of "inarticulate biological life" prefigures any other, ${ }^{6}$ devaluing or gradually robbing people of their agency as self-representations of victimhood lead to a "de-selving" as narratives of strength and resilience are silenced, generating a destructive erosion of subjectivity.7 Whilst Ticktin and others argue that "survivors of violence are silenced as subjects, and as anything other than victims," ${ }^{2}$ stripped of agency, moral conscience, economic potential, or political awareness, ${ }^{9}$ when we broaden our gaze to consider how refuges are engaging with both humanitarianism and human rights, a more nuanced picture begins to emerge. Here, in an ethnographic exploration of the actions of HRD and the shape that "rights"-understood as "rights talk, rights thinking, rights practices"10_assume when local discourses of human rights interpenetrate with discourses of humanitarianism, the analytical possibilities extend beyond a critique of victimization and objectification towards a critical engagement with the voices of refugees demanding to govern themselves.

At the centre of this analysis is thus a focus on how HRD engage with what Fassin terms a "humanitarian politics of life," which occurs when a distinction between lives that can be narrated in the first person (those who intervene) is established with lives that are recounted only in the third person (the voiceless in the name of whom intervention is done). ${ }^{11}$ This article examines what occurs when refugees work to trouble this humanitarian politics of life as they strive to reclaim the first person voice as those who intervene from within, and the implications for defenders who seek to operate as "the voice of the voiceless" whilst being simultaneously constituted as voiceless themselves.

\section{Encountering Human Rights Defenders: An Ethnographic Methodology}

The experiences of HRD recounted within this article were shared with me during fieldwork I conducted in Uganda between January 2011 and October 2012. Based mainly in Kampala for this continuous period, I interviewed over three hundred Congolese refugees as part of an ethnographic analysis of refugees' perspectives on violence, humanitarianism, and human rights. This article draws in particular on the narratives of eight Congolese HRD whom I followed closely, including Emmanuel, Fabrice, Patrick, and Pascal, ${ }^{12}$ with whom I established strong relationships over the course of my fieldwork. Their length of displacement varied; Emmanuel arrived in Uganda 2004, and Patrick in 2010. I met these men through my time in the field, discovering the names of individual HRD and the organizations they ran, from refugees who had either heard of or been beneficiaries of their efforts, or introduced to me by others working in the field. Many of these men spoke fluent English, with the exception of Pascal and Patrick, with whom I communicated in a mixture of French and Kiswahili. They had all attained higher education and been active as HRD in the DRC.

They told me their stories gradually and cumulatively and according to their own momentum and logics over time across multiple conversations and interviews. They shared many of their hours talking to me, and inviting me to participate in an extensive scope of voluntary activities they conducted across the dense and frenetic urban spaces of Kampala. As this article demonstrates, their work generated substantial personal risk, and as such their security was paramount, so I took great care to protect their safety, strictly maintaining their anonymity and confidentiality in the field and later in writing up, protecting my research artifacts, and reflecting upon our interactions and the spaces in which we met. A dialogic ethnographic approach was critical in engaging with narratives and memories of violence within forced displacement, and the agency of those who navigate and speak within contentious humanitarian, political, and legal orders. 
All the HRD I met were men, suggesting a male bias across both the realm of human rights defending and access to education and expert knowledge. I met many women engaged in community work, who were setting up and leading support and community groups. They very rarely, however, represented themselves as HRD, revealing one role that gender plays across the scope of human rights work. Human rights work in this context constituted a particularly male form of habitus, revolving around-to use their own words- "fighting against injustice without fear" and the "leadership or background like men," and whilst passionate advocates of women's equality, HRD also constructed human rights practice as "activities which must do by men," as Patrick put it. I repeatedly overheard Emmanuel telling the young people he worked with, "To start something you have to struggle, to have that vision. A man is one who has faced challenges, [that is] when they can call you a man.”

\section{"They call them the law of the people": Congolese Defenders in the DRC}

The DRC has been the site of enduring conflicts on the local and provincial levels since the struggles for independence (1959-65), through thirty-two years of rule under kleptocratic President Mobutu, and the violence of the regional "Congo wars" (1996-7, 1998-2003). The Congolese population have faced protracted political violence engendering frequent forced population displacements both within and over its borders, and the near collapse of the health system and much state infrastructure. ${ }^{13}$ Millions of Congolese are estimated to have been killed through military action, malnutrition, disease, corruption, fighting over management of natural resources, and the inclusion/exclusion of citizenship rights among ethnic groups. ${ }^{14}$ The violence endures, particularly within the east, as many (inter)national protagonists continue to fight in fluctuating patterns of alliance and confrontation. To borrow Taussig's phrase, we might describe how a "state of emergency" faced by many Congolese has become not the exception but the rule, as human rights are violated on a mass scale within the context of individual and communal lives. ${ }^{15}$ Amnesty International reported in 2013 that more than 2.4 million people were internally displaced, and furthermore, hundreds of thousands had been displaced into neighbouring countries.

When I began to ask Congolese refugees about human rights I was repeatedly told that human rights-les droits de l'homme-were people. As one pastor explained, "Human rights: the name says they [are] supposed to protect humans, to talk on behalf of people. It can help people in difficult problem and look for way of solution." Micheline, sitting on a woven mat in front of me, a child slumped asleep across her lap, alongside her brother-in-law Katembo, told me her life story over eight hours, her voice gentle: "The human rights who was speaking on our behalf had been killed, we should just run. He told me, 'This case was politicized.' The reason for his arrestation was this case. He advised me 'to just go in any country, and see how they can help you."

As she paused, absently stroking the hair of her daughter, my research assistant, a refugee himself, turned to me urgently. "Here the population protects people," he told me, not for the first time. Micheline nodded. Katembo, who had been sitting quietly on the mat next to us, spoke up then to explain how "human rights are trying to help us but also they are fearing, under [the DRC] government. We are just here because we have human rights help us and other organizations try and defend our problems." And who are these "human rights," I asked. "Human rights, these people who are, give someone his rights and also defend people in their circumstance,"16 he explained. Jervais, a man who was forced to flee with his family from Kinshasa told me, "Human rights, from Congo they call them the law of the people. If I get a problem I go to the human rights, and they go. I don't have power, or no gun to fight [the Congolese] Government. Police can do nothing."

For much of the population of eastern DRC, my informants suggested that "human rights" refer not to abstract legal categories, but to the men who strive to protect and defend them in a landscape of violence and impunity. They are the individuals they hear about from their neighbours, listen to on the radio, or see active within civil society. Where "police kill people," they are the men who travel through perilous terrain to record and denounce massacres, who visit prisons and rebel groups, who stage marches and protests, who send detailed and meticulously researched reports to international and national agencies. In seeking to find loved ones who have disappeared, to appeal against violations sweeping through their communities, to make claims for justice and accountability against those perpetrating violence with impunity, these are the people who do not just act to "defend" people, to "give" them their rights, but they also come to inhabit the discourses that they deploy. They "are" human rights to the population.

This was exceptionally dangerous work. One man told me, "We are just in a hole in Congo, the population cannot raise their voice. There is no democracy. Any time you can just die." "So human rights defenders are raising their voices?" I asked. He frowned, "Human rights could help people but they are silenced by the [Congolese] government. The government are silencing human rights." Awezaye, rescued from a rebel group by an HRD, described how "one human rights worked a lot, one sacrificed his life to talk on behalf of many. That is the reason he was killed, because he was defending many people. He was a very good man.” 
In contrast to how they were perceived in the population, these "human rights" referred to themselves strictly as "human rights defenders." These were, I was told by Fabrice, an HRD from Bukavu, South Kivu, "those who are supposed to talk on behalf of others who don't have the power or means of talking, the voice of the voiceless." When I asked who the "voiceless" were, the common response was simply, "They do not have the strength." In describing their work and selves, HRD thus used a different but no less embodied language to describe their work. Pascal was one such man. He was twenty-five and had fled the DRC five years previously after facing brutal persecution for his rights work. The first time we met, he introduced himself as an HRD: "You have first to know, this work of being a human rights defender, it must be voluntary first, it must come from you. I do it because I want to do it, it is my nature, it is in my blood. You must be willing to do this work."

He nodded as he spoke, running his fingers along the neatly divided papers of a folder in his lap comprising human rights reports he and colleagues had meticulously researched and written, interspersed with copies of (inter) national legislation. He continued, pointing his finger in emphasis, eyes wide in his small face: "Despite the fact that everyone fears to die, as human rights defenders you are aware of risk. If you sacrifice yourself you are not afraid. It is voluntary, no one is pushing you to do it, you sacrifice yourself to help others. I cannot say everyone, but sure there are others like me. I know some, we work together."

One of those he worked with was Fabrice, who in another conversation explained that being an HRD "is not [only] what you are, it is what you do." Didier, in his thirties, was a prominent refugee leader when I met him. He had been engaged in rights work in DRC for seven years before fleeing to Uganda. Meeting in the ramshackle shed used by his community organization as a classroom for refugee children in Kisenyi, he described being an HRD: "It is nature, be born with it. A humanitarian heart, [you] must have it in your nature. Be the voice of the voiceless. For me to be human rights defender, I discover myself, what is in my capacity of doing things? What is my rights? How to defend?"

For Justin, also in his thirties, defending was "all about passion, connections, help. We are trying to work, to see, we have hope things will change. To be the voice of the voiceless."

\section{Defending in Displacement}

The DRC's enduring violence has ensured that there is an accompanying protraction of displacement into neighbouring countries, where Congolese refugees find themselves at odds with the framework of emergency and short-term crisis that dominates many of the region's humanitarian interventions. The United Nations High Commissioner for Refugees (UNHCR) reported in 2013 that there were approximately 118,0oo registered Congolese refugees/asylum seekers in Uganda, ${ }^{17}$ but the true number was likely to be much higher. Upon arrival in Uganda, Congolese became bound by the Refugees Act 2006, a piece of legislation described in one humanitarian report as "progressive [and] human rights and protection oriented." 18 The current refugee policy in Uganda according to this Act and UNHCR policy is "premised on two pillars: the settlement policy and the self-reliance strategy (SRS). Under the former, refugees are required to reside in designated settlements, all located in remote, rural areas." ${ }^{\prime 19}$ Here they are eligible for material assistance, whereas under the latter, those refugees living outside of such settlements are not provided with any material assistance." ${ }^{20}$ In response to the hardships and restrictions associated with the settlements, tens of thousands of refugees decide to "self-settle" amongst the national population in border areas and the capital. ${ }^{21}$ The refugees I encountered had fled into a humanitarian space characterized by the widespread and systemic violation of critical refugee rights, particularly relating to welfare, freedom of association and expression, and work, in which durable solutions continue to remain elusive for the vast majority. ${ }^{22}$

Urban refugees live largely in the many slum belts of Kampala. Forced displacement from a long-term conflict zone, coupled with life in Kampala's slums, ensured many refugees faced multiple and complex needs, finding it difficult to secure permanent employment and places for their children in schools, and living in substandard housing with poor sanitation and security. Many exhibited complex health issues arising from violence experienced in the DRC and often years of poor, if any, medical treatment. Attending Ugandan humanitarian agencies thus became part of the daily routines of many, as they could often represent the only route to attaining health, legal, material, educational, and other necessary assistance. To access such humanitarian assistance and incite the empathy of strangers and Good Samaritans alike, many refugees had little choice but to engage in "victimcy," performing particular frames of victimhood and vulnerability, and repressing resilience, creativity, and action as they worked to conform to the behaviour of "true refugees" that humanitarian officials might consider credible. ${ }^{23}$ As Emmanuel wryly explained, when "going to [humanitarian] offices you put bad clothes, look like you're going to die today." In Kampala, as refugees engaged in strategic essentialism to produce their own victim identity they were, HRD argued, in danger of losing a sense of both self and hope. Patrick articulated this one day, sighing as he rubbed his moustache, "Refugees think everything is finish for them." One young widower called 
Julius was not alone in telling me, "For sure, when I consider the kind of life in Uganda, this is not the life a human being can go through. Since I am in Uganda life stopped for me."

The staff with which refugees interacted were overwhelmingly Ugandan, and this predominance of Ugandans working in what appeared to be an unwieldy, bureaucratic humanitarian machine augmented for refugees an entrenched divide between humanitarians and refugees, distancing refugees from the decision-making processes over their own cases, fuelling anxieties around documentation, and contributing to a culture of distrust that embittered many of the relationships between humanitarians and refugees. It also led to much frustration amongst those who had engaged with and conducted humanitarian work in the DRC for local, national, and international non-governmental organizations, particularly HRD, who decried both the lack of opportunities for refugees to secure employment and opportunities within the humanitarian realm.

In addition to their perceived inaccessibility, the regime was believed to be actively frustrating the attempts of refugees to help themselves, and refugees were thus forced to look to their own community for help. As one woman explained, "Here, yes, whenever you have insecurity problem, you can report to police, which cannot happen in Congo, but when you report you cannot get assistance. They do not protect everyone." Her eldest daughter, at sixteen, agreed: "[Humanitarian] refugee organizations-whenever you go there, they will listen to you and tell you what you are supposed to do, but they will not take any action." Further to this, her mother added, Ugandan human rights organizations "also they say that [there is] nothing [they] can do to assist us since we have organization dealing with refugees, and then refer us to the [refugee] office[s]." Therefore, as Patrick, an HRD, observed, "People are aware, since they fail to get assistance from any organizations working with refugees, they come to us." Congolese HRD were, in contrast, seen to be accessible and approachable. Embedded within their own communities, they were observed using the language of human rights to try to both ameliorate and seek redress for the suffering of refugees.

It never took long for HRD to re-engage in rights work in Uganda, mostly through the creation of community-based organizations. All the HRD I met were adamant that "there was no other work" for them "in this world." As Fabrice said of his arrival into Uganda, "Still I continue to work for human rights wherever I am going. I like being an advocate, to defend human rights until my death ... We human rights defenders, we have to take those issues."

For him it was the suffering he witnessed amongst refugee women, especially in the rural refugee settlements, that impelled him into action. He spoke passionately of the widespread lack of justice and protection for refugee women who had suffered sexual abuse. These women, isolated in the settlements, had little sympathy from local police, and no financial resources or knowledge of their rights to escalate or politicize their cases. Alongside "a colleague" he formed an organization and began to conduct research. He explained, "We interviewed many women, many of them are raped and there was no organization to defend. For us the field was just refugee women, it was the focus. We really made several campaigns. We had some recommendations, so many recommendations. We published a report that women were traumatized in Uganda. We saw many human rights concerns. We make actions. I have partners from Congo, I knew how to communicate to them, [for example] the African Commission for Humans and People's Rights. The [Ugandan] government was asked to report to ACHPR in 2009 on issues in that report."

In March 2009 Fabrice was invited to "present the experience of women" during an event for Sexual and GenderBased Violence (sGBV) Week in Kampala, sponsored by local humanitarian agencies working with refugees. He was told "the police, opm [Office of the Prime Minister], Ugandan authorities, UNHCR be there":

As human rights defenders we must present issues to them. My wish is the authorities hear women are suffering, must do something. I prepared twenty cases. It was a big seminar, they invited many partners. I went there, I presented human rights violations case by case. I show this case violated this article, this contravenes such articles. On the tenth case, all the cases are presented to show the police are responsible for human rights violations directly or indirectly. Now, on the tenth, I saw the police inspector get the police and said I should stop: [he said] "They abuse the police."

In using the language of rights to (re)construct the experiences of these refugee women into human rights violations, Fabrice claimed a legal subjectivity not just for them, but also for the refugee community as a whole. Social connections were critical. For many refugees, traditional and essential ties of kinship and community are fractured in the course of flight, rendering them isolated and vulnerable. The powerful and desperate realities of their persecution in the DRC aside, HRD had, like those they helped, arrived in Uganda with little or nothing, actively living and understanding the violence, disruption, and insecurity interwoven through the fabric of everyday life. Unlike most, however, they had the tools with which to reinscribe such complaints. Operating through diligent (re)constructions and interpretations of rights discourses within a visible public realm, their production and dissemination of reports constituted internationalized forms of fact-finding 
protocols in which human rights abuses were codified within standardized, often chronological formats. ${ }^{24}$ In so doing, for example, Fabrice became a conduit for these women to know and claim for their rights, exercising a narrative authority derived from experience, knowledge, and a position within both horizontal networks-as a refugee himself with access-to listen to these women, and vertically, within international and regional rights networks. They incorporated individual experiences into their own collective voices in speaking up to the Ugandan government, humanitarian regime, and regional rights platforms, implicating the international in the local.

\section{"You try to change the situation, that is human rights activity"}

Beyond classical human rights work of conducting research and gathering evidence within meticulous reports cataloguing human rights violations, HRD also conducted numerous practical activities to fill the service gap often left by humanitarian agencies. Their community-based organizations were not prominent in the humanitarian field in attracting funding and were often instead marginalized by more established nationally run (and internationally funded) humanitarian agencies. Nevertheless, they were well attended, respected and relied upon by the refugee community, occupying a critical hub for many men, women, youth, and children.

Their work could include helping people to negotiate the different humanitarian agencies and mandates, working out which agency offered which services, and sometimes accompanying refugees to Old Kampala Police Station or OPM when seeking asylum, or to local police posts whenever they had a complaint, such as robbery or assault. Many offered free English classes to all levels of competence, and some offered vocational training in different livelihood or computer skills for those across the refugee community. HRD could also help individuals and families seek sponsors, write letters, find health care and medication, or temporary and permanent places to live, and make connections across the community. Many offered counselling services or ran outreach activities such as gender-based violence programs. This work took on many guises yet was referred to under the umbrella of "that human rights" by both HRD and nondefender alike.

A charismatic man of twenty-six, Emmanuel had a forceful personality. Often clothed in bright colours, he could command any space. He had been active as a law student in Bukavu's civil society, "defending human rights, abuses of government soldiers, we sent reports to MONUC"25activities that brought him "into conflict with government soldiers." Faced with certain incarceration and/or death,
Emmanuel fled to Uganda in November 2004. Early in 2005, upon being granted refugee status, he was sent to Kyaka II refugee settlement where, aged twenty, he felt impelled to organize a group of young people to come together in protest. He explained, "I could not stay like that-no jobs, abuses of rights, commandant beating women, taking refugees as dogs. I was so popular in the camp, constructing latrines, [organizing] a championship of soccer. I was like community leader, like I am in Kampala today."

He formed an association that "wrote so many things, writing, lobbying, reports ... our purpose to show the rights of refugees need to be respected." As for Fabrice, Emmanuel sought to claim a position from which he could speak against those discursively constituted as the powerful interveners-the "practitioners of humanity." 26 He recounted how it was his "heart of human rights" that drove him to continue "fighting against wrong people in the system," even when now fighting those belonging to an altogether different system.

As a consequence, he was repeatedly attacked and detained by the settlement authorities. He was beaten, and the commandant falsely accused him of abduction in a bid to detain and silence him, part of a campaign through which he "became a bad name." He began to "hide," sleeping in a different house every night before escaping the settlement and walking for two days to a nearby trading centre and into the relative anonymity of Kampala. Rather than being silenced, however, all this had the opposite effect. Almost six years later he was pragmatic about how these events prompted him to take more care in framing his reports to "speak about good and bad points. [If] human rights activities put you in conflict, [you] try to change strategy." His work was nowadays conducted through a deliberately crafted trail of stamps and paperwork, drawing a self-protective bureaucratic shield around his activities. His passion for helping young refugees surged unabated, his focus now turned to "home care," providing shelter, education, medical help, and counselling for "unaccompanied minors." He operated with energetic zeal, directing his passion into helping young people to transform themselves away from what he called "that mind of despair." As he explains, "My project is to help remove that mind. Uganda is a very good country, you can do what you want, you are a refugee just in documentation. You try to change the situation, that is human rights activity.

Emmanuel was not alone in highlighting the emancipatory potential of human rights. Justin was another HRD who spoke of being driven by his desire to "raise up young people." Tireless at thirty, he was always on the move, hurtling between voluntary activities of his vibrant community organization. He described how "people have to think how 
to make yourselves free, the government is not doing anything, the elections are the same, promises from government, nothing has changed." His work "to empower dispossessed young refugees" was critical, he argued, "to overcome the burdens of deprivation and vulnerability to become healthy, educated, self-sustaining and contributing members of society ... I give them hope, show them everything is possible."

Peter, who worked closely on occasion with Pascal, explained such an approach: "Refugee-led organizations play a big role, they change the picture of local perception, they give a totally different perception-refugees solving problems of being refugees. Refugees are made part of development, they are partners."

Nyamnjoh argues that there can be a tendency in the uptake of human rights in local spaces to minimalize the power of society, social structures, and communal and cultural solidarities, ${ }^{27}$ whilst Merry warns of how when local activists use a language legitimated by a global consensus on standards, this political space can come at a price. Human rights can displace alternative visions of social justice that are less individualistic and more focused on communities and responsibilities, possibly contributing to the cultural homogenization of local communities. ${ }^{28}$ This article demonstrates how in Congolese HRD in Uganda, almost the opposite is true. Whereas the humanitarian regime-and its language of human rights-is seen by refugees as inaccessible and repressive, when rights are reclaimed and wielded by HRD from within they are seen to hold real potential for articulating and challenging local and humanitarian power structures, and promoting communal and cultural solidarities. Ideas of human rights are used by HRD to promote individual and collective autonomy and establish new forms of social relations concerned not with dependence on aid or humanitarian assistance, but aspirations to self-governance and sustainability. A critical engagement with local rights vernaculars to navigate humanitarianism extends our understanding of the multiple and rich ways refugees experience, understand, and resist the subjugation of humanitarian aid. Yet these too are enmeshed within webs of entrenched inequalities, requiring attention to their own inner contradictions.

\section{"Human rights activities put you in conflict": Contradictions in Human Rights}

This final section examines how local cultures of rights are entangled in power and voice: who can and cannot speak, what they can say, and how their words are shaped and received. Goodhart observes how in certain situations human rights can be contentious, reflecting and reinforcing particular power and privilege at work. ${ }^{29}$ A political understanding of human rights here can draw attention to an important distinction between their use in emancipatory work, and their "misuse" as a means for domination and oppression. A focus on the contradictions arising in the human rights landscape reveals how human rights can be used as a tool for marginalisation and enforcing social hierarchies, or obstructing those already disempowered from the ability to articulate their grievances. ${ }^{30}$

HRD were quick to recognize, name, and denounce the relations of power and subjugation within what they tellingly called the "refugee management system," contesting the failings of a humanitarian regime that was paradoxically saturated with the language of rights. In spite of, perhaps even because of, the efficacy of their actions, HRD-in their work to invoke the responsibilities of those in authority to defend, rather than violate, the rights of refugees-encountered both domination and oppression across multiple levels. One form this took was through formal political exclusion enshrined in law, ${ }^{31}$ whilst another arose within informal interpretations of the "political."

Rights practice was frequently interpreted and inscribed as political by those in authority-whether humanitarian or state actors-leading to the marginalization of HRD. Pascal told me about one case he had taken on. He had worked with a woman whose thirteen-year-old granddaughter was "defiled" by a Ugandan man who was granted police bail after his family gave money to the police post where he was jailed. He explained, "When we saw the case is very bad, we decided to publish and talk to the [police] authorities who have power, we don't have power. We are following the case and are in danger." He was accused of being "engaged in politics" and threatened with arrest himself. Such marked power inequalities described by Pascal created the conditions in which quotidian rights work was recast by those in authority as "political," allowing for and sanctifying the oppression and silencing of defenders and refugees more widely. Pascal pointed out the irony of such accusations levelled at those most legally literate: "How can we engage in political activities when we are refugees here? The law in the country of asylum is that we cannot be political. We do not want to be involved in politics."

In their simultaneous use and condemnation of human rights, the Ugandan government could thus deploy the language of human rights in its discourse of refugee protection to international donors, whilst at the same time portraying HRD as illegally engaging in "politics." This effectively demonized them as being antagonistic to the government who had benevolently provided them with "refuge," revealing how human rights can be (mis)used by agents of domination to disempower, marginalize, and silence those who denounce them. Many HRD were overtly critical of the implication of the humanitarian regime within the Ugandan 
government, observing a contrast to their experience of navigating humanitarian operations in eastern DRC. "The UNHCR is under government" was a constant refrain in our conversations. Months after I met Patrick, he revealed this darker side to defending. In "making lives better" he was aware that, as a result of his activities, "the Ugandan govern ment is involved. They now don't want any organization to resettle us. To live has become a big problem." When I asked him how he did continue to live he shrugged, "What remains for us is courage, otherwise we would not survive." Fabrice offered further reflections on this repression: "In Uganda the resisting force is the government. They are resisting the activity of human rights defenders. These governments, they are the ones responsible for human rights violations, directly or indirectly. We try to denounce these issues ... When we denounce we get a big problem, in all of Africa."

It is not just in the disciplining of defenders' voices that we can observe such contradictions in human rights practice. Not even two years after fleeing Bukavu for his life, Fabrice found himself entering a new nightmare in the aftermath of his public denunciation of the police in 2009: "We first started receiving threats by telephone. Eh! When we saw that, Amnesty International advised us to keep a low profile, we start managing our security." One month later Fabrice was abducted from his house and taken into custody. Arms bound behind him and his feet tied together, he was badly beaten in the vehicle before arriving at one of Kampala's notorious "safe houses." Here he was interrogated and tortured, his assailants demanding, "Why did you publish this information to the international community? Why are you making malicious against the government of Museveni?" Curled up against their blows, he still protested, crying, "For us we carry out investigation and publish reports, we want voices of refugee women to be heard by you and the international community so their human rights be respected." Unsatisfied, his interrogators continued to torture him.

To this day he does not know how the events unfolded exactly, but he was released after three days of illegal detention and torture, during which he was repeatedly threatened with death. He showed me two reports, explaining, "Frontline [Defenders] already published. The international community made pressure to the government." After receiving emergency treatment, he found a safe refuge. Vulnerable and facing intense precarity, Fabrice appealed to the UNHCR for assistance in leaving Uganda. However, as he recounts, "UNHCR now saw this case was against their priorities, they are like to work under government. They feared to work on my case, they could not protect me. Other organizations request them to resettle me. UNHCR said they could not, they gave me a rejection letter! That is terrible really."
His case reveals both an abuse of power and a failure in protection, but also the difficult intermediary position of humanitarian agencies, a kind of "double bind" experienced by organizations problematically positioned between the state and the members of vulnerable populations whose rights they ostensibly seek to protect. ${ }^{32}$ More crucially, however, is the precarity of those who operate both within this gap and as members of such a vulnerable population, often forced into a position of heightened vulnerability as those in intermediary positions reside in non-action.

Yet more troubling still is the role of these intermediaries in repressing those who attempt to speak out. A violent and corrupt police force aside, many HRD attested to the deep implication of the humanitarian regime in their suppression. Pascal told of how he and others had been repeatedly persecuted by the humanitarian actors whose weaknesses in responsibility to protect refugees' rights they sought to voice: "When you come out and speak openly to the international community you will become a target. They are organizing meetings against those talking about violations of human rights." I asked who "they" were. "I'm talking about InterAid, Office of Prime Minister, UNHCR, who meet to fight those who are talking about human rights violations. You see it will affect them one way or another. A refugee can go to meet you about his problem, to report a case, he can be arrested there. Human rights activities put you in conflict. While no protection of human rights, abuses continue."

Many others spoke of meetings in which defenders were unequivocally told to "be quiet and stay down" or their case files would be closed and any potential humanitarian assistance-particularly resettlement-revoked. This had happened to Peter, who wearily explained, in echoes of Emmanuel's experience in Kyaka II, "When you try to tell them about the rights of refugees they take you as a bad person."

It was not just within the humanitarian regime that the values of human rights were inconsistently supported. Whilst working tirelessly for the emancipation of some sectors of the refugee community, certain HRD were exercising their own power and exclusive privilege in repressing particular social and minority groups. As Englund cautions us, critical analysis of international human rights activism "subverts its own objectives if it does not include activists" contradictory position in regard to human rights." 33 Didier represents an (extreme) example of the messy and often hierarchical nature of rights work. It was only after knowing each other for several months that I discovered he was playing an active role in a campaign against what he referred to as "another problem now in our community"-that of "homosexuality." He was assertive in arguing how "in our community it cannot be acceptable, so we cannot allow it." Whilst representing a minority amongst the HRD I met in 
Uganda, especially when compared to others actively campaigning for minority rights, his case certainly reminds us to consider the rhetoric of HRD critically.

Niezen points to how whilst the central goal of human rights is "to better the conditions of those who are most blatantly victimized by states, it in practice empowers those who are most visible to publics." 34 Jamal, a young man who had fled to Kampala from persecution in a refugee settlement, told me how Congolese HRD "don't help LGBTI, 35 and also in Congo they don't support LGBTI people ... I tried to meet some human rights, he said he cannot follow that case. In practice, they choose some people, but they say they defend the human rights of all people. They are not defending, they marginalize us."

Jamal's words highlight the importance of interrogating the very notion of "the voiceless" evoked frequently, and uncritically, by HRD, to uncover the hierarchies and exclusions embedded within it. ${ }^{36}$ In being "the voice of the voiceless" HRD were paradoxically replicating the anonymity and invisibility generated by structures of oppression whilst simultaneously posing a challenge to it as highly visible and empowered agents. Whilst striving to have refugees' struggles seen and heard, they were simultaneously suppressing these same voices as they spoke on their behalf. In assuming such a visible position, however, they placed themselves at extraordinary risk. It might be unsurprising therefore, that for the wider population, the authority to "voice" human rights was rarely considered their own. Human rights, rather than inalienable rights belonging to every person, were instead conceived largely as not tools wielded by select, educated others, but as embodied in the HRD themselves.

\section{Conclusion}

An ethnographic account of Congolese HRD in Uganda offers insight into the competing discourses and articulations of power of those in positions of authority (humanitarians and state agents), the subjects of such power (refugees), and those subjects who resist power from within (human rights defenders). This analysis engages with and pushes beyond the significant theoretical and empirical literature on humanitarianism and human rights by drawing the two together. This not only provides a richer understanding of how humanitarianism and human rights are understood and articulated, but also resisted and subverted by those facing protracted forced displacement. It uncovers, in the process, the nuance and contradictions of local cultures of human rights in practice and reveals the underbelly of a humanitarian system using the discourse of rights to morally justify and animate their activities whilst simultaneously driving a regime that objectifies, depoliticizes, and marginalizes refugees.
HRD draw our attention to how humanitarianism violently occludes vulnerable people from the discursive and legal resources to communicate and politicize their subjugation. In refugees' perspectives, however, human rightsas enshrined not in law or text, but in the actions of Congolese $\mathrm{HRD}$-were perceived to enduringly hold distinctly more emancipatory potential in remaking worlds than any humanitarian policy or practice. Here human rights are seized upon as a language for not only critiquing the culture of powerlessness at work in Uganda's humanitarian regime, but also for framing the action taken to resist such subjugation and to promote individual and collective autonomy. HRD work to establish new forms of social relations concerned not with being dependent on aid or humanitarian assistance, but aspirations to self-governance. Such ideas and those who wield them are certainly problematic and are indeed enmeshed within their own webs of entrenched inequalities, yet a critical engagement with local rights vernaculars and other means for navigating humanitarianism extends our understanding of the multiple and rich ways refugees experience, voice, and resist the subjugation of humanitarian regimes.

Katie McQuaid is research fellow at University of Leeds. The author may be contacted at k.r.v.mcquaid@leeds.ac.uk.

\section{Notes}

1 An early version of this article was presented at "Refugee Voices: Refugee Studies Centre International Conference," Oxford, UK, 24-5 March 2014.

2 M. Duffield, Development, Security and Unending War: Governing the World of Peoples (Cambridge: Polity, 2007); D. Fassin, and M. Pandolfi, Contemporary States of Emergency: The Politics of Military and Humanitarian Interventions (New York: Zone Books, 2010); T. Kelly, This Side of Silence: Human Rights, Torture, and the Recognition of Cruelty (Philadelphia: University of Pennsylvania Press, 2012); D. Kennedy, “The International Human Rights Movement: Part of the Problem?," Harvard Human Rights Journal 15 (2002): 101-25; D. Meyers, "Two Victim Paradigms and the Problem of "Impure' Victims," Humanity: An International Journal of Human Rights, Humanitarianism, and Development 2, no. 2 (2011): 255-75.

3 L. Malkki, "Speechless Emissaries: Refugees, Humanitarianism, and Dehistoricization," Cultural Anthropology 11, no. 3 (1996): 378.

4 C. Colvin, "Ambivalent Narrations: Pursuing the Political through Traumatic Storytelling," Political and Legal Anthropology Review 27, no. 1 (2004): 72-89; K. Sandvik, "International Law and Security," in The Routledge Handbook of New Security Studies, ed. J.P. Burgess (London: 
Routledge, 2010), 4; K. Segall, "Postcolonial Performatives of Victimization," Public Culture 14, no. 3 (2002): 617-19.

5 M. Utas, "West Africa Warscapes: Victimcy, Girlfriending, Soldiering: Tactic Agency in a Young Woman's Social Navigation of the Liberian War Zone," Anthropological Quarterly 78, no. 2 (2005): 409.

6 G. Agamben, Homo Sacer: Sovereign Power and Bare Life (Stanford, CA: Stanford University Press, 1998).

7 M. Hajdukowski-Ahmed, "A Dialogical Approach to Identity: Implications for Refugee Women," in Not Born a Refugee Woman: Contesting Identities, Rethinking Practices, ed. M. Hajdukowski-Ahmed, N. Khanlou, and H. Moussa (New York: Berghahn Books, 2008), 40; P. Kea and G. Roberts-Holmes, "Producing Victim Identities : Female Genital Mutilation and the Politics of Asylum Claims in the United Kingdom," Identities: Global Studies in Culture and Power 20, no. 1 (2013): 99; H. Ghorashi, "Agents of Change or Passive Victims: The Impact of Welfare States (the Case of the Netherlands) on Refugees," Journal of Refugee Studies 18, no. 2 (2005): 181-98; S. Jensen and H. Ronsbo, eds., Histories of Victimhood (Philadelphia: University of Pennsylvania Press, 2014); R. Zetter, "Labelling Refugees: Forming and Transforming a Bureaucratic Identity," Journal of Refugee Studies 4, no. 1 (1991): 39-62.

8 M. Ticktin, "Sexual Violence as the Language of Border Control: Where French Feminist and Anti-Immigrant Rhetoric Meet," Signs: Journal of Women in Culture and Society 33, no. 4 (2008): 884.

9 C. Nordstrom, Girls and Warzones: Troubling Questions (Uppsala: Life and Peace Institute, 1997), 36.

10 J. Cowan, M. Dembour, and R. Wilson, eds., Culture and Rights: Anthropological Perspectives (Cambridge: Cambridge University Press, 2001), 11-14.

11 D. Fassin, "Humanitarianism as a Politics of Life," Public Culture 19, no. 3 (2007): 519.

13 L. Roberts, Mortality in Eastern DRC: Results from Five Mortality Surveys by the IRC (Bukavu: DRC, 2000).

14 International Rescue Committee and Burnet Institute, Mortality in the Democratic Republic of Congo (2008), http://www.rescue.org/sites/default/files/resourcefile/2006-7_congoMortalitySurvey.pdf.

15 M. Taussig, The Nervous System (London: Routledge, 1992), $10-34$.

16 Emphases added.

17 UNHCR Uganda, "2015 UnHCR Country Operations Profile: Uganda,” http://www.unhcr.org/pages/49e483co6.html.

18 Refugee Law Project, Refugee Law Project Critique of the Refugees Act (2006), 3.

19 C. Clark-Kazak, Recounting Migration: Political Narratives of Congolese Young People in Uganda (Montreal and Kingston: McGill-Queen's University Press, 2011), 31-2.

20 L. Hovil, "Self-Settled Refugees in Uganda: An Alternative Approach to Displacement?," Journal of Refugee Studies 20, no. 4 (2007): 568-9.
21 Ibid., 601.

22 M. Sharpe and S. Namusobya, "Refugee Status Determination and the Rights of Recognized Refugees under Uganda's Refugees Act 2006," International Journal of Refugee Law 24, no. 3 (2012): 562; Hovil, "Self-Settled refugees," 599.

23 M. Utas, "West Africa Warscapes"; E. Friedman and R. Klein, Reluctant Refugee: The Story of Asylum in Britain (London: British Library, 2008), 59.

24 W. Hesford and W. Kozol, Haunting Violations: Feminist Criticism and the Crisis of the "Real" (Chicago: University of Illinois Press, 2001), 5.

25 Mission des Nations Unies au Congo-the United Nations mission in DRC at the time.

26 A. Ong, Neoliberalism as Exception: Mutations in Citizenship and Sovereignty (Durham, NC: Duke University Press, 2006), 198.

27 F. Nyamnjoh, "Reconciling 'the Rhetoric of Rights' with Competing Notions of Personhood and Agency in Botswana," in Rights and the Politics of Recognition in Africa, ed. H. Englund and F. Nyamnjoh (London: Zed Books, 2004), 33.

28 S. Merry, Human Rights and Gender Violence: Translating International Law into Local Justice (Chicago: Chicago University Press, 2006), 4.

29 M. Goodhart, "Human Rights and the Politics of Contestation," in Human Rights at the Crossroads, ed. M. Goodale (New York: Oxford University Press, 2013), 34.

30 Ibid., 36,38 .

31 Under "Part V: Rights and Obligations of Refugees" of the Refugee Act 2006, this is referred to twice, under Article 29: Rights of Refugees while in Uganda, $1(\mathrm{~g})$ where it says refugees "have a right of association as regards non-political and non-profit making associations and trade unions," and in Article 35: Duties and Obligation of Refugee, which goes into more detail on not engaging "in any political activities within Uganda, whether at local or national levels," or undertaking "any political activities within Uganda against any country, including his or her country of origin."

32 D. Goldstein, "Whose Vernacular? Translating Human Rights in Local Contexts," in Goodale, Human Rights at the Crossroads, 114.

33 H. Englund, Prisoners of Freedom: Human Rights and the African Poor (Berkeley, CA: University of California Press, 2006), 8, 145 .

34 R. Niezen, "The Law's Legal Anthropology," in Goodale, Human Rights at the Crossroads, 196.

35 Lesbian, gay, bisexual, transgender, intersex.

36 I examine the case of Congolese refugees belonging to sexual and gender minorities elsewhere. See K. McQuaid, "Violent Continuities: Telling Stories of One Sexual Minority Life in the African Great Lakes region," Identities: Global Studies in Culture and Power 21, no. 5 (2014): 570-85. 